\title{
Law as a Social Construction and Conceptual Legal Theory
}

Dan Priel

Osgoode Hall Law School of York University, dpriel@osgoode.yorku.ca

Source Publication:

38(3) Law and Philosophy 267 (2019)

Follow this and additional works at: https://digitalcommons.osgoode.yorku.ca/scholarly_works

Part of the Public Law and Legal Theory Commons

\section{Repository Citation}

Priel, Dan, "Law as a Social Construction and Conceptual Legal Theory" (2019). Articles \& Book Chapters. 2751.

https://digitalcommons.osgoode.yorku.ca/scholarly_works/2751

This Article is brought to you for free and open access by the Faculty Scholarship at Osgoode Digital Commons. It has been accepted for inclusion in Articles \& Book Chapters by an authorized administrator of Osgoode Digital Commons. 


\title{
Law as a Social Construction and Conceptual Legal Theory Dan Priel"
}

\author{
Forthcoming 38 Law and Philosophy (2019).
}

\begin{abstract}
A currently popular view among legal positivists is that law is a social construction. Many of the same legal philosophers also argue that before one can study law empirically, one needs to know what it is. At the heart of this paper is the claim that these two propositions are inconsistent. It presents the following dilemma: if law is a social construction like all other social constructions, then legal philosophers have to explain what philosophers have to contribute to understanding it. Studies of social constructions are typically conducted by historians, sociologists, and others, who explain them (and what they are) on the basis of empirical data. If, as legal philosophers claim, conceptual clarification must precede empirical work, then it follows that the lack of conceptual work on the nature of other social constructions renders suspect all empirical work on them. To avoid such a radical conclusion, legal philosophers may argue instead that law is a social construction of a special kind. But to say that is to undermine the premise with which the argument began. Moreover, this response to the dilemma collapses what is now taken to be what separates legal positivism from natural law theory, thus undermining the motivation for this view. I conclude the essay by offering a different solution to the dilemma by suggesting that it shows that the fundamental debates of legal philosophy are not conceptual but political.
\end{abstract}

I.

It was not that long ago that many used the formula "no necessary connection between law and morality" to describe a central tenet of legal positivism. For example, H.L.A. Hart wrote that "positivist jurisprudence...like Bentham's and my own work denies that there is any conceptual or necessary connection between law and morality." Jules Coleman and Brian Leiter endorsed this formula in a survey article on legal positivism. ${ }^{2}$ And, writing in the same year, Leslie Green said that "Kelsen is a positivist-[in his view] law may have any content and there is no necessary connection between and morality." 3

"Associate Professor, Osgoode Hall Law School, York University. I thank Vincent Chiao, Chad Flanders, and an anonymous referee for Law and Philosophy for their comments on earlier drafts of this essay.

${ }^{1}$ H.L.A. Hart, Essays on Bentham: Studies in Jurisprudence and Political Theory (Oxford: Clarendon Press, 1982), pp. 262-63; see also H.L.A. Hart, "The New Challenge to Legal Positivism”, Oxford Journal of Legal Studies 36 (2016): 459-75, pp. 460-61.

${ }^{2}$ Jules L. Coleman, \& Brian Leiter, "Legal Positivism”, in Dennis Patterson (ed.), A Companion to the Philosophy of Law and Legal Theory (Oxford: Blackwell, 1996), 241-60, p. 241.

${ }^{3}$ Leslie Green, “The Concept of Law Revisited”, Michigan Law Review 94 (1996): 1687-1717, pp. 169192. 
Attitudes quickly changed. Many legal positivists (including some of those just mentioned) have come to see the "no necessary connection" slogan as "absurd" and its association with legal positivism a "myth." ${ }^{4}$ With the so-called "separability thesis" now abandoned, what was left of the distinction between legal positivism and natural law? In recent writings, legal positivists have shifted their attention to the idea that law is a social phenomenon. Green wrote that one of the central messages to be taken from Hart's Concept of Law is that "[1]aws and legal systems are not matters of nature but artifice. We might say they are social constructions." Jules Coleman stated that "the core of legal positivism is the social facts thesis" ${ }^{1}$ according to which law consists only of social facts. Andrei Marmor said that one of central ideas accepted by all legal positivists is that "law is, profoundly, a social phenomenon." Notably, all three considered this idea as a mark of distinction between positivist and non-positivist views on law. ${ }^{8}$

I will call those who hold this view "social constructionists of law," or "social constructionists" for short. Importantly, such constructionist claims are themselves presented not as empirical observations about law in any given time or place, or even as a record of prevailing attitudes about law. They are said to be conceptual claims about the nature of law. By calling them "conceptual" I mean that these claims are said to be true of law wherever and whenever it is found, regardless of people's attitudes on the matter. This point was stressed by Marmor when he distinguished between an account of the nature of something and what people think about it: "Thought...even if it is collective and public, as revealed by language use-is never a guarantee of truth. The fact that we collectively think about something in a certain way does not mean that things are that way." Though this claim as stated is implausibly strong-it suggests that an entire society can be mistaken about the reference of "black" or "currently fashionable"its message is clear: An inquiry into the nature of law is not an exercise in sociology. This implies that the claim that law is a social construction is not itself thought by its proponents to be a social construction. ${ }^{10}$

${ }^{4}$ John Gardner, Law as a Leap of Faith: Essays on Law in General (Oxford: Oxford University Press, 2012), p. 48.

${ }^{5}$ Leslie Green, “Introduction”, in H.L.A. Hart, The Concept of Law, 3rd ed. (Oxford: Oxford University Press, 2012), p. xvii.

${ }^{6}$ Jules L. Coleman, “Beyond Inclusive Legal Positivism”, Ratio Juris 22 (2009): 359-94, p. 383.

${ }^{7}$ Andrei Marmor, Law in the Age of Pluralism (Oxford: Oxford University Press 2007), p. 36.

${ }^{8}$ Coleman, "Beyond", pp. 383-85; Marmor, Law in the Age, p. 37; Green, "Introduction", pp. xvii-xviii.

${ }^{9}$ Andrei Marmor, "Farewell to Conceptual Analysis (in Jurisprudence)", in Wil Walchow \& Stefan Sciaraffa (eds.), Philosophical Foundations of the Nature of Law (Oxford: Oxford University Press, 2013), 209-29, p. 213; see also Gardner, Law as a Leap of Faith, pp. 276-77.

${ }^{10}$ In addition to the authors mentioned in the text, Shapiro states that "[s]ocial science cannot tell us what the law is because it studies human society." Scott J. Shapiro, Legality (Cambridge: Harvard University Press, 2011), pp. 406-07 n. 16. Green has argued that jurisprudence fixes the subject matter for sociology, such that if sociologists were to ignore these categories, they may end up offering "a sociology of something 
This is not a marginal point. If the claim that law is a social construction were a social construction, it would be an empirical claim, whose truth would call for empirical evidence. To social constructionists of law, however, the idea that law is a social construction is a pre-sociological, "philosophical" or conceptual finding about the nature of "law itself." ${ }^{11}$ The significance of this point is that, if true, it identifies a domain for a distinctly philosophical inquiry about law.

To further clarify the social constructionist thesis we must distinguish between two possible ways of understanding it. In its weak version, the thesis only stands for the idea that particular laws are social constructions. In this form the claim is uninteresting. It is not in question that the content of laws in different legal systems is different, or that this content is different as a result of the actions of humans. Moreover, the weak version of the social construction thesis does not help distinguish legal positivism from natural law. I do not know of anyone, including Cicero, Aquinas, and other expositors of "classical" natural law theory, who denied it. Turning to our times, a few years before legal positivists began proclaiming the sociality of law as the core of legal positivism, John Finnis had already written that law is "a cultural object, constructed, or...posited by creative human choices, [and which] is an instrument, a technique adopted for a moral purpose, and adopted because there is no other available way of agreeing over significant spans of time about precisely how to pursue the moral project well." 12

The social constructionist thesis is therefore interesting and potentially controversial only if it is made stronger. In its stronger version the social constructionist thesis does not relate only to particular laws, but to the idea of law itself. Here, if the sociality of law is to serve as the basis for a distinction between legal positivism and natural law theory, it must be because natural lawyers think that what law is, is not fully captured by the fact that it is a social construction. On this understanding, natural law theory is the view that one cannot have a complete understanding of what law is without acknowledging its non-socially constructed elements.

An analogy with language will help to distinguish the two versions of the thesis: If the Chomskian view of language is true, there is an important sense in which language

other than law." This, he added, "gives jurisprudence some priority" over sociology. Green, "Introduction", p. xlvii. Such statements show that those who search for the nature of law seek to identify something that does not depend on any contingent facts about humans, including any attitudes they may have about law.

${ }^{11}$ See Marmor, "Farewell”, p. 209; Gardner, Law as a Leap of Faith, pp. 276-77, 300-01; Shapiro, Legality, pp. 406-07; Green, "Introduction”, pp. xlvi-xlvii. Terminology here is often confusing. The sort of inquiry I have in mind is sometimes called "conceptual jurisprudence" to contrast it from "normative jurisprudence." Others, however, prefer to talk of the search for "nature of law" to distinguish it from the search for the "concept of law" (which in their terminology is a sociological inquiry). My argument is intended to capture all those who think that discovering the "nature," "essence," or "character" of law is a non-empirical inquiry, whether or not they call this inquiry "conceptual."

${ }^{12}$ John Finnis, "Natural Law and Legal Reasoning", in Robert P. George (ed.), Natural Law Theory: Contemporary Essays (Oxford: Clarendon Press 1992), 134-57, p. 141. 
is not a social construction. That does not mean that languages do not have an important component that is socially constructed; they obviously do. Chomsky's ideas were not meant to challenge the existence of very many socially constructed differences among languages. His views about the innateness of universal grammar were challenging because he rejected the then-popular view that saw language as socially constructed all the way down. Without pushing the analogy too far, we can understand the strong social constructionist thesis applied to the legal domain as the claim that law is wholly socially constructed. So understood, natural law theory is somewhat akin to Chomsky's position-law, especially particular laws, are socially constructed, but there is a nonsocially constructed element to law-while legal positivism is the denial of this view. The social constructionist thesis is thus interesting, and provides a way of distinguishing legal positivism from natural law theory, if it insists that law is socially constructed all the way down.

With this clarification, I can proceed to presenting the argument of this paper, which can be briefly stated as follows: If law is wholly a social construction, this casts doubt on the practice of jurisprudence as a conceptual (non-empirical) inquiry aimed at discovering the nature of law wherever and whenever it is found.

It would help to present the social constructionists' view in terms of two commitments:

(1) It is a conceptual truth about law that it is a social construction.

(2) As a conceptual matter, law is $L$ (where $L$ stands for anything not logically entailed by $(1)) \cdot{ }^{13}$

My claim is that (1) and (2) are inconsistent. Less formally, my claim is that if law is a social construction and assuming (for the sake of argument) that this claim is itself a conceptual claim, then there are no other conceptual claims about law that are not true of all other social constructions.

There are two reasons why this claim, if true, is significant. First, in recent years there has been much controversy about jurisprudential methodology. More specifically, there have been many debates on whether or not jurisprudence has a distinctly conceptual part, a part that in no way depends on moral or political considerations and is perhaps logically prior to them. In an indirect way, these debates have addressed the question whether (1) is true. Some rejected (1) by arguing that jurisprudential claims about law are a product of a normative argument, others rejected it by arguing that all supposedly conceptual claims about law are, at best, empirical generalizations. The argument I advance here can skirt around these debates. For the sake of argument, I accept it as a conceptual truth that law is a social construction (all the way down) and argue that this is inconsistent with other conceptual claims made by social

\footnotetext{
${ }^{13}$ Those who prefer not to speak of conceptual jurisprudence can read the following instead of (2): (2') The nature/essence of law is $L$ (where $L$ stands for anything not logically entailed by (1)).
} 
constructionists about law. Second, as the opening paragraphs show, many legal positivists have now abandoned the separability thesis and consider the sociality of law to be the key for distinguishing positivist from nonpositivist views on law. What I say below casts doubt on this idea and so, if true, challenges the new orthodoxy about the core of legal positivism.

I begin my argument in a somewhat roundabout way by discussing three examples that at first do not seem to have much to do with any of these matters. The first example comes from a legal case. In the case in question the United States Supreme Court was asked to decide on whether the Americans with Disabilities Act required the Professional Golfers' Association Tour to accommodate Casey Martin, a golf player who suffered from a disability that prevented him from standing and walking for extended periods of time. Martin argued that the ADA required that he be allowed to use a golf cart during professional tournaments, something prohibited by the Tour's regulations. The majority held in Martin's favor, in part on the basis of their determination that walking is not an essential part of golf. In an acerbic dissent Justice Scalia poked fun at the majority's opinion. "It has been rendered the solemn duty of the Supreme Court of the United States," he wrote, "laid upon it by Congress in pursuance of the Federal Government's power ' $\mathrm{t}$ ] $\mathrm{o}$ regulate Commerce with foreign Nations, and among the several States'...to decide What Is Golf." ${ }^{14}$ These words are effective, because the suggestion that there is an answer to this question will strike almost everyone (with the possible exception of a few philosophers) as ridiculous. ${ }^{15}$

But let us not drop this question quite yet. If we accept Green's claim that law is a social construction, we are faced with an interesting puzzle: Both law and golf are social constructions, so why is it that the question "what is golf?" or any of its possible cognates (e.g., "is mini-golf really golf?") can at best be described as a slightly odd parlor game, whereas the question "what is law?" is deemed a worthy subject for academic conferences? One tempting answer is that law is very important for our lives while golf is not. But, even if true, this is only a contingent fact about law in our world. And if that

${ }^{14}$ PGA Tour, Inc. v. Martin, 532 U.S. 661, 700 (2000), quoting U.S. Constitution, Article I.

${ }^{15}$ Philosopher Scott Soames has indeed taken up the challenge. See Scott Soames, "Interpreting Legal Texts: What Is, and What Is Not, Special about the Law", in Philosophical Essays, vol. 1 (Princeton: Princeton University Press, 2009), 403-23. He argued that Scalia is mistaken, because he took Scalia to argue that the essence of golf is fixed by its rules. I think he misunderstood Scalia's point (who quite clearly rejected this view), but as this has no bearing on my argument, I will not pursue this issue. On the matter at hand, it seems Soames thinks that on the essence of "what we mean by golf...there is no higher authority than its use by competent speakers." Ibid., p. 407. This means that his position is that the essence of golf is fixed by people's attitudes as to what counts as golf (rather than by the rules of golf). Soames thus takes the essence of golf to be fixed by what most people think counts as golf. As this is an empirical fact, Soames's view gives no support to the social constructionist position I consider in the text. 
is indeed the reason for the difference, this suggests that jurisprudential inquiry must be subject to some kind of evaluation of its practical value for humans. ${ }^{16}$

In any event, this response is not available when comparing law to other social constructions. Consider a second example, derived from Ronald Coase's first major article. ${ }^{17}$ In that article, Coase attempted to provide an answer to the question why companies exist. This may seem like a strange question to ask, but within a particular socio-political discourse it is a pertinent one: Companies are islands of command-andcontrol, of planned economy, within a sea of market capitalism. If, as we are often told, markets will always beat a planned economy, why aren't private contractors driving companies out of existence? Coase's insight-transaction costs-would eventually win him a Nobel Prize.

My final example comes from a book by one of the leading American tax lawyers of the twentieth century, Stanley Surrey. In that book Surrey expounded and analyzed certain legal entities he called "tax expenditures." ${ }^{18}$ Tax expenditures are ways of promoting certain goals through certain tax benefits rather than through budgetary outlays. Surrey noted that though the aims of tax expenditures and budget expenditures were often similar, their structural difference (payments versus tax reductions) and their different location (the budget versus the tax code) led to them being treated very differently. The former were a matter of "expenditure control" whereas the latter were treated as "tax reform." Surrey's book considered in great detail the implications (sometimes unintended) of the choice between these two legal devices.

As should be obvious, I do not mention these works for what is in them, but for what's on their cover. Coase's thoughts on companies come from an article entitled "The Nature of the Firm." The subtitle of Surrey's book is "The Concept of Tax Expenditures." Surrey says in his book that upon returning to university after a stint in government he "continued the exploration of the concept of tax expenditures." And yet this mere tax lawyer did not think he had to recruit a philosopher to help him understand what a "tax expenditure (really) is," before applying to their answer his own expertise in determining when to opt for tax expenditures and when for budgetary outlays.

I am confident this attitude is reciprocal. If I were to call on philosophers to answer, as a conceptual matter, what counts as a firm, or if I asked philosophers to apply their refined skills of identifying the nature of objects to tax expenditures, I would not expect to find many takers. Why is that? Unlike golf, it is difficult to argue that these are unimportant social constructions. Importance is admittedly notoriously difficult to measure, but it is arguable (or, at least, has been argued) that "[t]he most important

\footnotetext{
${ }^{16}$ Contrary to the message of Gardner John \& Timothy Macklem, Book Review of Shapiro, Legality, Notre Dame Philosophical Reviews (2011), http://ndpr.nd.edu/news/27609-legality/.

${ }^{17}$ R.H. Coase, “The Nature of the Firm," Economica 4 (1937): 386-405.

${ }^{18}$ Stanley S. Surrey, Pathways to Tax Reform: The Concept of Tax Expenditures (Cambridge: Harvard University Press, 1973).
} 
organization in the world is the company: the basis of the prosperity in the West and the best hope for the future of the rest of the world." ${ }^{19}$ True or not, it is hard to dispute companies are important enough; and yet their nature goes unstudied by philosophers. As for tax expenditures, valued by the United States Government Accountability Office at over $\$ 1.47$ trillion in 2017 alone, ${ }^{20}$ they can hardly be called trivial. Yet here too, as far as I know, legal philosophers have not rushed to aid their tax law colleagues.

Of course, it does not matter whether the study has the word "concept" or "nature" in its title, although it makes more vivid the point that here are two important social constructions (and there are hundreds like them) that no-one-not even philosophersthinks require some kind of conceptual elucidation, definitely not as a preliminary to their empirical, sociological investigation..$^{21}$ As these examples show, this is true even for concepts that play an important role in the law. This lack of interest from legal philosophers is particularly striking as many of them consider it valuable, perhaps even necessary, to engage in the analysis of concepts like promise or wrong before making normative arguments in areas such as contract or tort law. At a higher level of abstraction, we are told that one needs to know what law is, as a conceptual matter, before one can turn to evaluating its merits. ${ }^{22}$ It is therefore surprising that legal philosophers have not taken their own view more seriously and argued that the analysis of the concepts company and tax expenditure is a necessary preliminary to answering normative questions in company and tax law.

I suspect the reason philosophers do not volunteer to answer these questions is not because they think companies, tax expenditures, or even golf, are unimportant. It is because they do not think they have much to contribute to understanding them. Being social constructions the proper way to study them is by examining them empirically. Anyone seeking to know what tax expenditures "are," to explicate the "nature" or "essence" of a company, or to elucidate the concept of golf should either look into what

${ }^{19}$ John Micklethwaite \& Adrian Wooldridge, The Company: A Short History of a Revolutionary Idea (London: Weidenfeld \& Nicolson, 2003), p. xv.

20 See U.S. Government Accountability Office, Tax Expenditures: https://www.gao.gov/assets/700/691854.pdf.

${ }^{21}$ For those suspecting that the titles of Coase and Surrey reflect the linguistic carelessness of nonphilosophers who do not know what "the nature of" (or "the concept of") means, here is another example. Philosopher Richard Joyce in his book The Evolution of Morality (Cambridge: MIT Press, 2007) has a chapter entitled "The Nature of Morality." The chapter relies on, among other things, extensive anthropological data on human practices. I could easily provide many additional examples, from philosophical and nonphilosophical works. Though my argument does not depend on the title of any work, these examples show that the view that considers "the nature of $X$ " as a necessary preliminary categorical inquiry is an idiosyncrasy of contemporary legal philosophy, not a standard understanding either within or outside philosophy.

${ }^{22}$ Julie Dickson, "Ours Is a Broad Church: Indirectly Evaluative Legal Philosophy as a Facet of Jurisprudential Inquiry”, Jurisprudence 6 (2015): 207-30, pp. 215, 229. 
people think they are, or into how they operate in the world, or both. In any case, the inquiry calls for some kind of empirical investigation, not philosophical ruminations.

In short, studying the "nature" of objects is not typically understood as a philosophical preliminary to empirical inquiry, but-on the contrary-as its conclusion. This fundamental difference makes several questions salient: Is law different? And if so, in what way? The most natural answer for anyone who thinks that law is a social construction is that it is not different: There is nothing unique about law as social construction. But if this is the case, it is difficult to see why law is singled out for conceptual elucidation while leaving unstudied countless other social constructions. Even worse, if that is the case, it is difficult to see what such an elucidation could yield. If law is a social construction like any other, then its nature too should be studied empirically. If there is a question for philosophers to consider, it is not about the nature of law, but the nature of social constructions in general, on the assumption (which I granted for the sake of argument) that that is not a social construction. At the very least, one would have to explain the latter before attempting to explain the former. And absent unique features, which on this view by hypothesis do not exist, trying to answer the question "what is law?" as a conceptual (pre-sociological) matter looks like a confused endeavor, no different from the attempt to determine as a conceptual matter what counts as a tax expenditure. Such an inquiry involves the mistaken attempt of filling in the empirical ("sociological") details about a specific social construction by way of philosophical reflection.

Put somewhat differently, on this view law is a unique social construction, but it is unique in exactly the same way that all social constructions are unique, namely in its contingent features. Whatever features law necessarily has, it shares them with all other social constructions, and it has them in virtue of being a social construction, not in virtue of being law. The features in virtue of which something is law, on the other hand, are to be investigated empirically. This is an important point that deserves further elaboration. The question of identifying the origin and nature of social constructions is a topic to which philosophers have made important contributions (although here too their work is nowadays supplemented by the work of cognitive scientists and psychologists). The study of particular social constructions is the job of sociologists, anthropologists, social psychologists, historians, perhaps also economists and political scientists. It is not an inquiry that philosophers seem particularly interested in (as evidenced by their lack of interest in explaining the nature of thousands of other social constructions), or for which they developed any reliable research methods.

It follows from what I have said so far that if law is a social construction like other social constructions, then whatever is said to be necessarily true of law in general must be necessarily true of all social constructions. Here is one illustration of this point. John Gardner wrote that "Hart was...offering a solution to the philosophical puzzle...[:] How can there be 'jurisdictions' with their own laws? How is it possible that one law ends at 
San Diego and another begins at Tijuana?" If law is a social construction, there is no puzzle here; it is what we would expect. And that is precisely the response Gardner offers on behalf of Hart: "Hart's answer relied upon the simple idea that different social rules prevail at different times and in different places." ${ }^{23}$ This is not an important insight about law; it is a familiar observation about all social constructions, noticed by anyone who ever spent some time in more than one country.

To summarize the argument so far: If (1) is taken to mean that law is a social construction in the same way that golf, companies, or tax expenditures are, it is hard to see what role a non-empirical inquiry into their nature can offer. The right way to understand law is by investigating it in the same way we investigate the rest of the human-created world, by way of empirical inquiry. This implies that (1) and (2) are inconsistent.

II.

To counter what I have said so far forces social constructionists of law to redefine their claims. One way they may do so is by conceding that all they can provide in answer to the question "what is law?" is offer a negative claim, something like "it is a mistake to think that law is not just a social construction." So understood, the social constructionist thesis merely seeks to correct the errors of those who think that law is more than just a social construction, but it does not advance any substantive positive claim about the nature of law.

On this construal, the question social constructionists of law should try to answer is not "what is law?" but rather "why is it wrong to think that law is not (just) a social construction?" Though the two questions are related, they are very different. The crucial difference is that if legal philosophers advanced the negative thesis, they would not attempt to give an account of the nature of law. They would only be in a position to challenge those who held mistaken views about law being a social construction. Put in terms of the outline argument mentioned earlier, a proponent of the negative thesis will argue that it follows from (1) that there is no $L$ for which (2) is true. After making the negative claim, the proponent of (1) will concede that further inquiry into what law is should be handed over to those who study social constructions using empirical methods.

And here lies the problem for the legal philosophers, especially legal positivists, who have defended the social construction thesis. For in reality social constructionists of law do not stop at the negative claim. Instead, they typically proceed from arguing (1) to trying to give an account of the nature of law, i.e. to give a version of (2). For example, social constructionists have argued that law is necessarily the union of different kinds of rules, that all law is necessarily posited, that all law necessarily claims authority, and much else. Crucially, all these claims are being presented as non-empirical, necessary

${ }^{23}$ Gardner, Law as a Leap of Faith, p. 280. 
truths about all law, which obtain regardless of what people think on the matter. In addition, these features are said to be distinctive of law, not of social constructions in general.

The negative-claim response to my argument does not help the social constructionist, because it affirms that (1) and (2) are inconsistent. Anyone who accepts the negative claim should rephrase claims currently presented as conceptual truths about the nature of law as empirical hypotheses about legal practice in a certain time and place, or as prevailing attitudes about law. If empirically validated, these findings may well be important and illuminating; and they may be called, if one so wishes, a "theory of law." But the word "theory" will be used here in a sense much closer to the way it is used in most scientific contexts, namely as a way of organizing a body of empirical data, not something that precedes such data. In short, rather than being a central plank in a conceptual account of the nature of law, the negative thesis wholly undermines the possibility of having one.

To challenge the argument made so far, the social constructionist of law may contend that I implicitly relied on the following premise:

(3) Law is a social construction like other social constructions (e.g., golf, company, and tax expenditure).

It is only with this premise that the argument presented so far can go through, but the social constructionist might argue that (3) is in fact false. To show this, the social constructionist will have to explain what makes law not fully a social construction, or what makes it a special kind of social construction. I am not familiar with social constructionists of law who have attempted to explain the ways in which law is unique as a social construction. Quite the contrary, the claim that law is a social construction is often presented in broad, unqualified terms, as part of an effort to demystify law, to disentangle it from the supposed obscurities of natural law theory. In other words, the social constructionist who rejects (3) faces a problem with (1): To defend (3) is to believe that (1) is strictly speaking false and must (at least) be qualified. It also suggests, that the substantive question "what is law?" cannot be adequately answered until we have an idea of the ways in which law is unique in relation to other social constructions. Indeed, if law is a special kind of social construction, one would expect legal philosophers to address this aspect of law's uniqueness as part of, or perhaps prior to, addressing the question "what is law?" itself.

Even if taking this route, it is important to recognize that not all answers will vindicate the possibility of conceptual jurisprudence; in fact, some plausible explanations of the uniqueness of law as a social construction will undermine it. Consider first the possibility that law is a functional kind, i.e. a kind membership to which depends on a function it performs. I have doubts about existing formulations of this view, and it is also notable (and I think not a coincidence) that social constructionists 
have rejected it, ${ }^{24}$ but I will nonetheless consider it here. With artifacts, their function is usually fixed by the intentions of the artifact designer. Roughly, for something to count as a clock it has to be designed to tell time, and to be capable of doing so. Some objects may acquire a (new) function, when someone chooses to use them in a particular way: a book or even a rock (non-artifact) may be used as doorstops, and thus "become" doorstops because someone has repurposed them (as it were) by deciding to use them in this way. Here too, then, there is a contingent intentional action that fixes the identity of object as a particular functional artifact, albeit not one of designing an object, but of designating it.

Thus, there may be some general features that all functional kinds share, but the specific function that a given object performs and in virtue of which it belongs to a kind is an empirical matter. If law is a social construction that happens to be a functional kind, the same must be true of law: There may be some general features it shares with other functional kinds, but the investigation of the specific function law serves, the one in virtue of which something counts as law, is a matter of empirical investigation. Once again, if law differs here from other human constructions (social or physical), it follows that the claim that law is a social construction is not the simple claim it was presented to be, but must be qualified. It suggests that law is some kind of sui generis, something that calls for an explanation of the differences between law and other kinds of social construction.

It is true that some legal theorists thought that the function law serves is a question of philosophical, not empirical, discovery. But-and this is a crucial point-these theorists are opposed to the idea that law is a social construction. ${ }^{25}$ My argument explains why: If law's function is a matter of empirical discovery, if it depends on the attitudes of a designer, this is not to be learned by philosophical investigation.

Another possible attempt to distinguish law from other social constructions might be based on the alleged universality of law to all human societies. It has been suggested that (unlike golf, companies, or tax expenditures) law is a human universal. ${ }^{26}$ This happens to be a controversial claim, but I need not take sides on the matter here as I use it here for illustrating my argument. If law is a universal social construction, its universality is puzzling. Golf, companies, tax expenditures, and most other social constructions are not found in all human societies, so why is law different? In a different

\footnotetext{
${ }^{24}$ See Green, "The Concept of Law Revisited", p. 1711; Kenneth M. Ehrenberg, The Functions of Law (Oxford: Oxford University Press, 2016), pp. 50-51, 193.

${ }^{25}$ See Michael S. Moore, "Law as Justice," Social Philosophy and Policy 18(1) (2001): 115-45. Moore explicitly defended the view that an unjust law is not law, i.e. something that is perceived by members of a certain community as law is not really law. In other words, Moore's account of what counts as law (as well as what counts as $a$ valid law) is premised on the idea that law is not a social construction.

${ }^{26}$ Steven Pinker, The Blank Slate: The Modern Denial of Human Nature (London: Penguin, 2002), p. 437, following Donald E. Brown, Human Universals (New York: McGraw-Hill, 1991).
} 
formulation, if it is true that law is a universal social construction, the real puzzle about law is the precise opposite of the one that troubled Gardner: not why law takes different form in different societies, but why there are no human societies without it.

A universal social construction is not an oxymoron. As mentioned earlier, language is instantiated differently in different communities and to that extent it is socially constructed, but there is (if Chomsky is right) something non-social about language that makes it a human universal. Perhaps law is like language in this respect. To hold this view does not require thinking that law or legality are somehow innate human traits, but if law is indeed a human universal, one would expect this fact to be part of an account of its nature. That, however, would not help the social constructionist for methodological as well as substantive reasons. Methodologically, the hypothesis in question depends on an a posteriori discovery, based on empirical, contingent facts about human nature or the conditions of life on earth. As such, it is something that conceptual jurisprudence, which proclaims to be a pre-sociological inquiry completely free of any empirical facts about humans, ${ }^{27}$ cannot say anything about. To adopt this view would imply that the philosophical work on the nature of law must be fundamentally reoriented to take account of empirical work on human nature.

Substantively, such a view amounts to a rejection of the idea that law is a social construction "all the way down." It only supports the weaker social constructionist thesis, which, as mentioned, is uncontroversial. To adopt this view is thus to affirm, rather than challenge, the central tenet of natural law theory. As the words quoted from Finnis in the beginning of this essay show, natural lawyers need not even deny that law is a product of human endeavor or that it is a constructed cultural object. What natural lawyers typically insist on is that no general account of law will be complete if it considers law purely as a matter of social construction, what they deny is that law is socially constructed all the way down. Depending on the particular version, one finds natural lawyers arguing that it is non-socially constructed facts about (among others) value, morality, practical reason, nature, human nature, or God, that are essential to any adequate account of law.

It was precisely the denial of point that has been a key element in legal positivists' rejection of natural law theory. Central to contemporary legal positivism has been the insistence that a philosophical account of the nature of law need not, and should not, rely on any such facts. Its proponents have insisted that a theory of law should be completely independent of any facts about human nature, and that it is metaethically, morally, and politically neutral. ${ }^{28}$ The claim that law is a social construction, and legal positivism more generally, have both been presented as the conclusion of this

\footnotetext{
${ }^{27}$ See sources cited in note 10.

${ }^{28}$ For example see Hart, Essays on Bentham, p. 28. Further examples are cited in Dan Priel, "Toward Classical Legal Positivism," Virginia Law Review 101 (2015): 987-1022, pp. 1011-12.
} 
theoretically-thin view of law. Much of the motivation for legal positivism, and more specifically for the idea of law as a social construction, has been a conscious attempt to rid legal philosophy of the perceived excess metaphysical and moral baggage that came with natural law theory. ${ }^{29}$

Since the present response to the argument presented in this paper affirms only the weak version of the social constructionist thesis (which natural lawyers accept), it does not present a distinctive positivist position. Even worse, this response concedes the basic challenge of natural law theory to positivist theories of law, namely that law is not quite a social construction in the way that, say, golf is. To be sure, there may still be disagreement on what the non-socially constructed element of law is, but the result looks much more like an intra-familial dispute within natural law theory, rather than its rejection.

III.

The argument advanced so far can be summarized in syllogistic form. As this is an outline, it is not meant to supplant the more detailed presentation above, but it aims to capture the main argumentative moves made in it. Those who wish to challenge this argument should pinpoint where they see its fault.

(i) Law is a social construction (taken from Green, Marmor, and Coleman).

(ii) Golf is a social construction (I assume this to be uncontroversial).

(iii) Legal positivists affirm, and natural lawyers deny, premise (i), and this marks the difference between legal positivism and natural law theory (taken from Green, Marmor, and Coleman).

(iv) It is a philosophical, pre-sociological, task to answer the question "what is law?" a question about which all humans may be mistaken (taken from Green, Marmor, and Shapiro).

(v) It is not a philosophical, pre-sociological, task to answer the question "what is golf?" or any other kind of social construction. Rather, this is a sociological inquiry (based on the absence of philosophical investigation of thousands of social constructions, and on the lack of philosophical concern with the elucidation of the concept or nature of golf).

The juxtaposition of (iv) and (v) creates a puzzle. How could it be avoided?

(A) By rejecting (v): There is room for a philosophical (non-sociological, conceptual) inquiry into the question "what is golf?," what is a company?," "what is a tax expenditure?" along with a host of others, such as "what is fascism?," and "what is a hipster?" Answering these questions does not depend

${ }^{29}$ Hart, Concept of Law, p. 188. 
on any facts about human nature or human society, and these are questions that humans may get collectively wrong.

Alternatively,

(B) By rejecting (iii): Law is a special kind of social construction, which is why the question "what is golf?" (etc.) is a sociological question, whereas there is room for a philosophical inquiry into "what is law?"

The choice between (A) and (B) is the central dilemma I pose in this paper. To adopt (A) has several unpalatable implications: First, it raises the question of why law has been subjected to intense philosophical elucidation when thousands, if not more, other social constructions have been left unstudied by philosophers. If all social constructions are in principle valid subjects for a conceptual study of their nature, it is odd that virtually all of them have been neglected by philosophers. Second, the absence of philosophical analysis of the nature of all these social constructions is not a mere intellectual curiosity. It casts serious doubt on vast swaths of empirical research on social constructions. After all, if we take seriously Marmor's words, quoted earlier, that " $[t]$ hought...even if it is collective and public, as revealed by language use-is never a guarantee of truth," or if we take seriosusly Green's claim that "before anyone can start counting anything we need to know what counts as what," 30 then all empirical study currently in existence of virtually all social constructions looks suspect. The claims just quoted are completely general and unqualified; taken at face value, they imply that we cannot write a history of golf, before we identify by way of philosophical reflection (independent of human attitudes on the matter, and in terms of "necessary and sufficient conditions" ${ }^{31}$ ) what golf is. Third, as the words just quoted show, the social constructionist view seems to rest on a very strong version of Platonism with respect to law, golf, hipsters, and pretty much anything else. This is, to say the least, surprising. The view presented as a way of avoiding the supposed heavy metaphysical commitments of natural law theory, now appears far more metaphysically ambitious than its rival.

For these reasons (B) may seem look like the more attractive alternative. Unfortunately, while it avoids the problems just mentioned, it is beset by different ones. First, it shows that (i) is false, which implies that legal philosophers have to explain in what sense law is similar to other social constructions and in what sense it differs from them. Such an explanation cannot just show that law is a different social construction from (say) golf; such an account must explain what it is about law that makes it amenable to philosophical elucidation in a way that golf is not. Second, as mentioned, since at least some natural lawyers have not denied that law is a social construction, to affirm (B) looks like it requires abandoning (iii). Without further explanation-currently not on offer-

\footnotetext{
${ }^{30}$ Leslie Green, “The Forces of Law: Duty, Coercion, and Power,” Ratio Juris 29 (2016): 164-81, p. 179.

${ }^{31}$ Ibid.
} 
accepting (B) undermines any clear distinction between legal positivism and natural law theory. Not only does accepting (B) collapse the legal positivism/natural law divide, it does so by endorsing the latter.

There is another way out that avoids both horns of this dilemma: rejecting (iv), i.e. rejecting the philosophical search for the nature of law. This possibility may seem preposterous at first. Against a backdrop in which inquiries into the nature or essence of law are seen as the core task of legal philosophy, rejecting (iv) may seem to imply that the whole field of general jurisprudence must be excised. Against currently dominant views, such a conclusion may seem so obviously false as to call into question the entire argument presented here. The purpose of the following brief remarks is to explain why this is not the case.

Champions of the conceptual approach do not deny that there is an important normative component to jurisprudence, but they often argue that the conceptual and the normative inquiries are fairly independent, and (more significantly) that there is some kind of logical priority of the former over the latter. ${ }^{32}$ Rejecting (iv) suggests this view is mistaken, and with it the entire foundation of conceptual legal theory. This is a large topic that deserves a separate discussion. ${ }^{33}$ Instead, here I will offer some brief historical remarks that may explain why rejecting (iv) does not mean the end of jurisprudence. For most of its history, what is known as the philosophy of law was taken to be a branch of moral or political philosophy. It is only in the twentieth century, on the heels of the hugely influential work of Hart (himself probably influenced by the earlier work of Hans Kelsen), that the purely conceptual study of law became the primary form of the philosophy of law in general. Hart's Concept of Law put this idea right in its title, and it has been pursued with ever greater zeal in subsequent decades. Inadvertently, though, the opening pages of Hart's book suggest an alternative. Hart wonders there why people care about the question "what is law?" but not about the question "what is chemistry?" It is a good question, and one that Hart never really answered. The history of jurisprudence does. The reason why people care about the question "what is law?" is because they think it matters, and it matters when understood in political terms. This way we can make sense of the question "what is law?" and explain the interest in it (as well as why it seems so intractable) while avoiding the dilemma of conceptual legal theory.

\footnotetext{
${ }^{32}$ Dickson, "Ours Is a Broad Church," pp. 215, 229; Gardner, Law as a Leap of Faith, pp. 275-76; Green, "Introduction," p. xlvi.

${ }^{33}$ See Dan Priel, "The Misguided Search for the Nature of Law" (unpublished manuscript), available at http://ssrn.com/abstract=2642461. See also Dan Priel, "Jurisprudential Theories and Descriptivism," Problema 8 (2014): 483-518. The argument in the latter essay is independent of but complementary to my remarks in this paragraph. I consider there a different puzzle about jurisprudential disagreements-their persistence-and argue that it is best explained by the fact at bottom jurisprudential disagreements are not conceptual (or descriptive) but normative.
} 
Instead of thinking about the question "what is law?" as akin to the question "what is golf?" I suggest we think of it as more similar to the question "what is democracy?" Democracy is also a human invention, but when (or if) people ask "what is democracy?" they do not ask what democracy is (conceptually), before turning to the question why it is good. Their answers to the two questions are deeply connected: Answering "what is democracy good for?" (or, "why democracy?") is inextricably connected to the question "what is democracy?" It is by answering the former question that one comes to an answer to supposedly "conceptual" questions such as, "Is democracy consistent with judicial review of legislation?," not the other way around.

Now, turn back to law: Augustine's famous question-"Remove justice, and what are kingdoms but gangs of criminals on a large scale?" 34 - can be seen as one attempt of positing the question "What is law?" in a way that makes the political aspect of the question salient. It compares law with something that may have the external appearance of law but is in reality a sham, no different really from organized robbery. There is nothing obscure or "metaphysical" about this way of thinking, no more than saying that not every state that has some majoritarian voting procedures is a democracy. ${ }^{35}$ When understood this way the question "what is law?" is a political question, not a conceptual one, for it seeks to identify some political element that separates "real" law from what merely looks like law. Significantly, this way of understanding the question "what is law?" is not undermined by the argument presented here. It is not meant to be a conceptual, morally-neutral inquiry, true for humans just as much as it is true for alien societies. ${ }^{36}$ On the contrary, answers to it will depend on arguments from political theory as well as on facts about human nature or the world humans find themselves in.

Augustine was not alone in thinking about law in this way. It is a staple of both the great classics of the field such as Thomas Hobbes's Leviathan and even, on a less ambitious scale, many of the works of jurisprudence from the first half of the twentieth century which are now largely forgotten. All these works addressed the question "What is law?" by blending empirical, conceptual, and political considerations. In the Whig history of jurisprudence, the separation of the conceptual from the political is presented as an example of philosophical progress, of getting past early confusions. It is this very distinction that explains why Hart's work is seen as a veritable advance over Hobbes's. This essay suggests a different view. It should therefore not be read as implying the end of jurisprudence, only the more modest claim that legal philosophers should adopt Hobbes, not Hart, as their model.

${ }^{34}$ Augustine, The City of God, trans. by Henry Bettenson (London: Penguin, 2003), p. 139.

35 Consider Yashca Mounk, “America Is Not a Democracy," The Atlantic (March 2018): 80-87. Whether or not one agrees with the thesis of this article, there is no conceptual difficulty in understanding its claims.

${ }^{36}$ Shapiro, Legality, p. 407. 